\title{
The Reform and Innovation of Using CDIO for Reference Taking Dalian Neusoft Institute of Information as an Example
}

\author{
Guo Xin ${ }^{1, a}$, Zhai Jifang ${ }^{2, b}$ \\ ${ }^{1}$ Education Institute, Dalian Neusoft Institute of Information, Dalian, Liaoning, 116023, China \\ ${ }^{2}$ Education Institute, Dalian Neusoft Institute of Information, Dalian, Liaoning, 116023, China \\ aemail: guoxin@neusoft.edu.cn, bemail: zhaijf@neusoft.edu.cn
}

Keywords: Reform; Innovation; CDIO; Dalian Neusoft Institute of Information;

\begin{abstract}
CDIO is the latest achievements of international engineering education, Dalian Neusoft Institute of information, using the CDIO for reference, creatively walk out of new way of China-style CDIO. This paper introduces the reform impulse and the innovation practices of Dalian Neusoft Institute of Information
\end{abstract}

\section{Introduction}

Engineering education of our university is in an awkward position now: On the one hand, the number of higher engineering education entrants has surpassed 4, 180, 000, ranking first in the world. On the other hand, engineering talent quality comes low in world rankings, just like "a good man caught in difficult circumstances". CDIO, as the latest achievements of international engineering education, open up a new challenges and practical road for engineering education in our country. Dalian Neusoft Institute of Information, using the CDIO for reference, creatively walk out of new way of China-style CDIO.

\section{The Impulse of Using CDIO for Reference}

Using CDIO for reference is not easy. We must pay attention to the international, domestic and university's own problems and requirements at different historical development stage. We should stick to historical engineering education basement, and also new innovation requirements; we should deep the reform to break through the obstacles, and also reach the greatest degree consensus in system.

A. why do we revert to engineering?

In the 1950s, the Soviet Union launched the satellite and the world the first astronauts go to space travel, which strengthen the proportion of the engineering science research in higher education of the United States. After the 1960s, college teachers are replaced by a group of people with doctor degree, these people are not engineers in the industry, but they bear the responsibility of training engineer, which lead to "weak engineering practice” phenomenon. In the 1980s, the Europe and the United States in engineering fields found that there is a big gap between engineering talents and the requirements of industry. In 2000, some of the world famous university like MIT proposed "return project" slogan. With the support of the Nobel Foundation \$16000000, CDIO engineering education model are developed and extended.

B. Traditional Chinese IT Education appears misplacement phenomenon

IT industry compared to traditional industry, it has its own trait. In China's traditional industries, universities and research institutions usually affects the technological transformation of enterprises with the new theory and new technology; while in the IT industry, advanced technology and equipments are always produced and created by IT enterprise, universities and research centers fared relatively poorly in the passive situation. That is to say. the main battlefield of IT education is in the enterprise, rather than in the University; This leads to the misplacement between the society requirements and IT personnel cultivation in Colleges and universities. So Chinese IT education 
needs to "return project".

C. The demands for Dalian Neusoft Institution of Information

"Education creates students values" is the education philosophy of Dalian Neusoft Institution of Information, it is the pursuit and further extension of the Neusoft group "people-oriented, common development"; the idea highlights "student-oriented", it regarded the students as the core source of College resources and competences, regarded students cultivation as the value of college. This corresponds to the keynote of CDIO engineering education.

Form the first batch of students in 2001 to 2008, Neusoft has been carrying out the philosophy of engineering education, has also made the enormous approval by the consensus and society, but there is still a gap in education system, comprehensive, complete, normative. Using CDIO systematically and creatively for reference is a huge demand for Dalian Neusoft Institution of Information.

\section{The Practice of CDIO Engineering Education Reform and Innovation}

Since 2008, Dalian Neusoft Institute of Information creatively constructed "TOPCARES-CDIO" talent training mode, and carried teaching reform based on the "TOPCARES-CDIO", and formed undergraduate teaching characters of the integration of production and learning, distinctive features and better apply.

A. Focus on stakeholder requirements, construct the standard system of TOPCARES-CDIO talents training

The stakeholders of university is multiple, university personnel training standards should also be diversified. Therefore, the demand of Dalian Neusoft Institute of Information concerned stakeholders' requirements, and constructed the TOPCARES-CDIO talent cultivation standard. From its name, "TOPCARES” means "top concern", it highlights that the leadership of the Neusoft group and the college pay much attentions to talents quality, demonstrates the basic idea "student-oriented", strengthens and refines the education philosophy of education students to create value. From the content of view, TOPCARES is a combination of the first letters of 8 English words. "T" refers to Technical knowledge and reasoning; "o" refers to Open thinking and innovation; "P" refers to Personal and professional skills; "p" refers to Personal and professional skills; "C" refers to Communication and teamwork; "A" refers to Attitude and manner; " $\mathrm{R}$ " refers to Responsibility; "E” refers to Ethical values; "S" refers to Social contribution by application practice; The TOPCARES index is consistent with CDIO program; there are 8 first grade indexes, 32 two level indexes and 110 three level index. From the school vision, to all the classes, training objectives, curriculums, formed the talents training system

$\mathrm{T}$ (Technical Knowledge and Reasoning)

O (Open Thinking and Innovation)

P (Personal and Professional Skills)

C (Communication and Teamwork)

T (Technical Knowledge and Reasoning)

A (Attitude and Manner)

R (Responsibility)

E (Ethical Values)

S (Social Contribution by Application Practice)

B. At th e core of knowledge, ability, quality, Making the integration of TOPCARES-CDIO talent training plans

The TOPCARES-CDIO talent training program is composed of three parts: the curriculum integration, progressive project design, the integration of inside and outside class project design. The Curriculum integration is combined of the professional knowledge, ability and quality, is combined with intelligence factors and non-intelligence factors, and establishes the mapping from the professional training objectives to the curriculum system, from the curriculum goal to teaching objectives. In the meanwhile, the enterprises and other stakeholders participate in the course design, 
project construction, and the formation of integrated curriculum system. Stepwise diminishing program is classified by 4 stages. The 1st stage program, called cornerstone project and capstone project, refers to the comprehensive project with core curriculum and ability, focus on the cultivation of professional core ability of students; The 2nd stage program, called Project Curriculum Group, refers to a group related core curriculum courses project; The 3rd stage program, called Curriculum Project, refers to the course to reach the course targets and enhance the ability; The 4th stage program, called Cell groups project, it refers to more than 2 units (module) program, it aim to strengthen the talent apply ability.

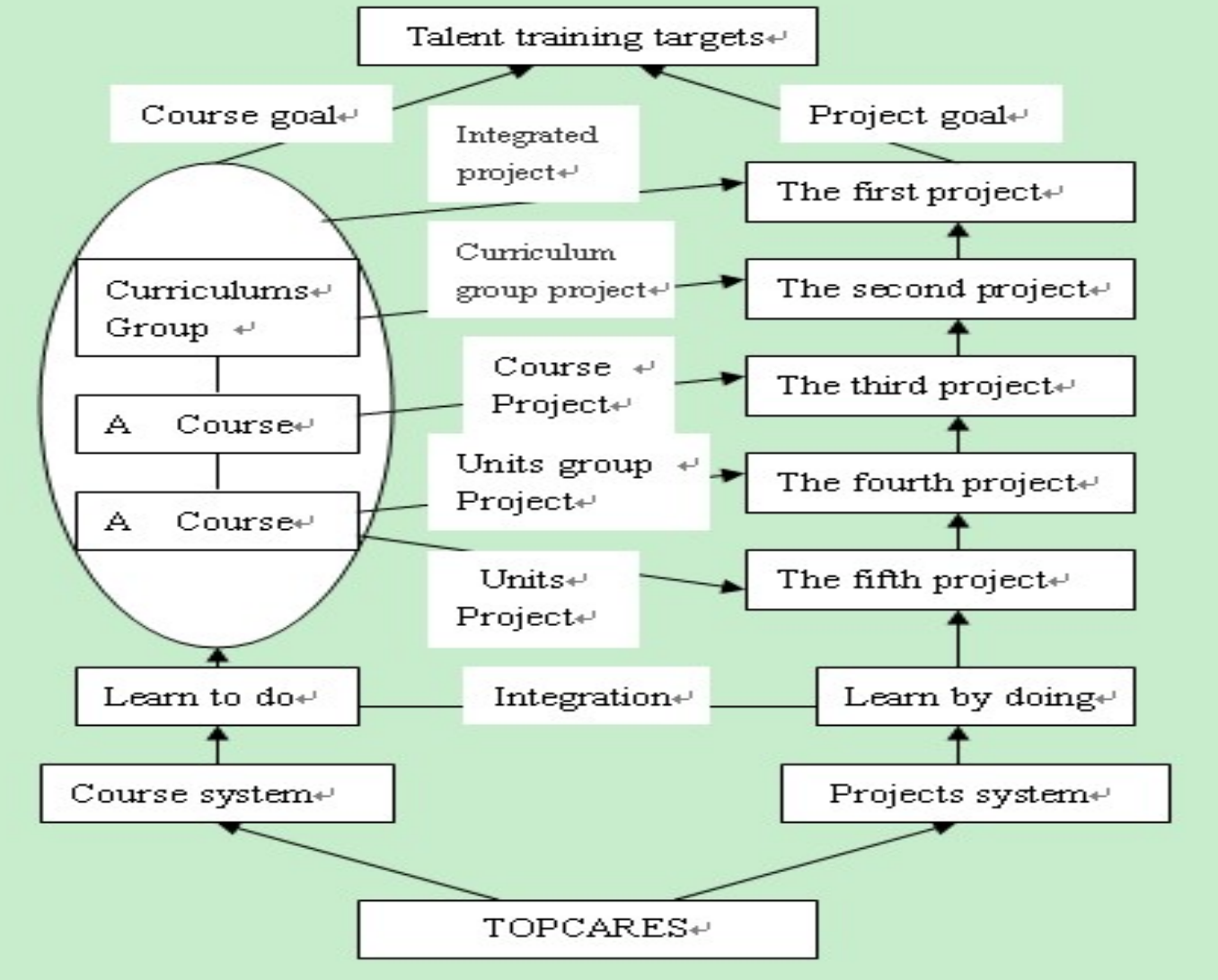

Pic.1.the model of curriculum integration constructure

C. Advocate of "Learning by doing", and emphasize the practice teaching modes and methods

"Learning by doing" is the method of learning, raised by American famous educators Dewey in nineteen twenties. With the application of this method to engineering education, combining school-based characteristics of Dalian Neusoft Institute of Information, it derived from five aspects:

Firstly, less theory teaching and more practices.

Secondly, develop advanced practice training teaching. In the process of teaching, adhere to the project as a guide, the design and implementation of project run through the four years of University Teaching. There are three terms in our university, two for theory study and one for practice the college also implemented the " $3+1$ " teaching mode, it means that on the basis of three years of study before, students completed "capstone" project in the last year.

Thirdly, open the customized training course. The colleges and enterprises jointly to provide teachers, to complete the course teaching, to participate in the whole process of talent training, and students successfully completed the transition from "student" to "staff".

Fourthly, carry out diversified assessment to training talents, and assessment runs through the whole process of class, including attendances, class performances, the experiments, project practices and final examinations. The organizations of assessment can be college, professional team, professional teachers, class group, SOVO company; and the evaluators of assessment can be teachers, student self-assessment, peer assessment and evaluation of enterprise etc.

Fifthly, perfect the interaction mechanism between enterprises, schools, and teachers, and improve teachers' practical ability; college take "approach, employment, training, evaluation" 
approach to improve the teachers' ability of engineering practice; We invite professionals from industry to be our instructors, and meanwhile our teachers been dispatched to industry to learn and update their knowledge base; and some enterprises just collaborate with us to set up joint labs for our students. And then, our university reforms the teacher's assessment system and adds practice ability as an important assessment and evaluation factor of teachers.

D. Taking advantage of the resources of the enterprise, create and adapt to the talents training mode of TOPCARES-CDIO practice environment

The first step of industry-university cooperation is to form a complete chain of cultivating talents, so we must work with industry, we must create a very good environments that adapt to TOPCARES-CDIO personnel training mode.

First of all, create a "3A" practice teaching environment, "3A" refers to the Anytime, Anywhere, Anyway. Students can participate in practicing projects at any time, at any place and in any way. Our university cooperate with well-known enterprises, including INTEL, IBM, SAP, and HP, Toshiba to develop IT education teaching management system, curriculum system, teaching materials and courseware, practical case. Our university also built nearly 50 professional laboratories which covers computer software, electronic commerce, integrated circuit, digital arts and other fields, and provides a good opening experimental environment for our students.

And then, construct teaching training resources system. Aiming to cultivate IT engineer, we develop enterprises teaching case based on TOPCARES-CDIO talent training mode, and establish a number of training teaching resource system, including Java, embedded, NET, website design, system maintenance etc.

Furthermore, set up students' entrepreneurship center, we called Student Office and Venture Office. SOVO was established according to the actual software enterprise environment. There are more than 30 SOVO of different professional directions which run by them. These "The Virtual Corporation" can get financial support from our university and some enterprises, and with the guide of enterprises tutors and university teachers actively participate in the ITO, BPO, web development services.

\section{Conclusion}

In summary, there is of great practical significance and far-reaching historical significance for using CDIO engineering education comprehensively, systemically, completely for reference in china. Because of this, the reform and innovation is very complex and difficult. The organization within the height, Front human resources preparation, institutional and organizational innovation factors, are the keys to success.

\section{References}

[1] Wen Tao, Dalian Neusoft Institute of Information records (2000 - 2005), Neusoft electronic publishing, Dalian

[2] Wen Tao, Dalian Neusoft Institute of Information records (2006 - 2010), Neusoft electronic publishing, Dalian

[3] Wen Tao, the exploration of IT modern education, China Education Daily, 2001 - 7 - 14

[4] Gu Peihua et al, to recognize engineering education, higher education press, Beijing: 2009 